\title{
Conventionalism and Theory of Meaning ${ }^{1}$
}

\section{Konvencionalismus a teorie významu}

\author{
Jindřich Černý \\ Filozofická fakulta \\ Univerzita Hradec Králové \\ Rokitanského 62, 50003 Hradec Králové \\ jindracerny@gmail.com
}

\begin{abstract}
Abstrakt/Abstract
What is conventionalism in philosophy of science? Basically, it is a thesis about empirical underdetermination. According to Conventionalists, there is "a slack" between our theories and experience that is to be "lined" with conventions. As the experience does not "impose" any theory, scientists are always free to choose a theory on "softer" non-evidential grounds when facing empirical underdetermination. "Conventionalism is a philosophy of freedom," as Édouard Le Roy put it. Yet the thing to remember is that there is no such a thing as the conventionalism. Reasons for empirical underdetermination that Conventionalists state are not always the same, hence it is more convenient to talk about varieties of conventionalism. The present paper is an attempt to sketch a line between two basic variants of conventionalism which are instrumentalism and constructivism.
\end{abstract}

Co je konvencionalismus? V nejobecnější rovině se jedná o tvrzení o empirické poddeterminovanosti. Podle konvencionalistů existuje "mezera" mezi zkušeností a teoriemi, která může být překonána pouze pomocí konvencí. Vědci si podle konvencionalistů mohou vybrat teorie na základě měkkých kritérií, protože teorie nikdy nejsou předepisovány zkušeností. Konvencionalimus je, jak jednou poznamenal stoupenec jeho radikální varianty, Édouard Le Roy, "filozofii svobody." Konvencionalismus by však neměl být považován za homogenní proud. Konvencionalisté se v podstatných ohledech různí v názorech na příčiny empirické poddeterminovanosti, což je i důvodem, proč je př́hodnější hovořit o variantách konvencionalismu. Předložený článek je pokusem vymezit dvě základní varianty konvencionalismu: instrumentalismus a konstruktivismus.

\footnotetext{
${ }^{1}$ Práce na studii byla podpořena z IP projektu "Otázka relativismu ve filosofii a společenských vědách" řešeného na Katedře filozofie a společenských věd Filozofické fakulty Univerzity Hradec Králové.
} 


\section{Two Ways of Conventionalism: Instrumentalism and Constructivism}

According to many, conventionalism is a homogenous movement. Conventionalism "in singular" is best described as follows:

1. Some statements that scientists acknowledge are apparent; they are not genuine statements. Axioms are statements of this kind. Axioms are nothing but definitions that can neither be true nor false.

2. The choice of definitions is free. To choose definitions is to engage to a language whose rules must be obeyed.

3. Every language is an empty form waiting to be "filled with" contents.

4. Contents are empirical. Forms and contents are strictly separated from each other. The only place where forms and contents meet are so-called "coordinative definitions" that coordinate language forms with objects in reality.

5. Of three traditional kinds of statements, only two remain, namely synthetic $a$ posteriori statements and analytic a priori statements. Synthetic a priori statements are simply erased from philosophy.

6. When responding to a negative empirical outcome, the language-users are free to modify either axioms or coordinative definitions.

Instrumentalism is a logical positivist version of conventionalism. The only task of theories is, as Carl Gustav Hempel used to say, "to extract empirical juice" from sentences which are confirmed, either directly or indirectly, by observation: to draw further consequences from observational reports. ${ }^{2}$ As theories do not have any other task to fulfil, they are nothing but simple instruments of prediction. The hope of supporters of instrumentalism is to get by with references of empirical vocabulary without positing theoretical entities of any kind. The question that I try to answer in this paper is whether conventionalism is always instrumentalist? The answer seems to be "no", since there are philosophers of science belonging to the conventionalist tradition who were not driven by a desire to give an "empiricism-compatible" explanation of apriori and of necessity, most notably Henri Poincaré who was above all curious about reasons for the theory-choice given the empirical underdetermination. Hence, it should not surprise that Poincaré's concept of convention is different compared to the positivist one: for Poincaré, conventions are values (simplicity or "commodity", as he used to say) which help to determine the choice among empirically indistinguishable theories.

Six ideas put together form the core of "instrumentalism":

axioms are implicit definitions Every empirical theory can be divided into two parts. One is definitional, the other is empirical. Only elements that belong to the empirical

\footnotetext{
${ }^{2}$ See Hempel (1945).
} 
part have definite truth values; definitions lack them. Scientists are free to choose definitions provided they leave the empirical content intact.

empirical underdetermination For every theory, there is at least one empirically equivalent alternative. The choice between empirically equivalent theories is a choice between "ways of speaking" about contents.

There are other important differences between logical positivism and French conventionalism. In spite of those differences, two variants can be compared from a semantic and epistemological point view, namely with respect what they say about definitions and the scope of the underdetermination.

\subsection{Axioms as Definitions}

\subsubsection{Implicit Definitions}

Although the concept of implicit definition was coined in the 19 th century $^{3}$, it is often associated with Hilbert's philosophy of mathematics. According to Hilbert, the terms are defined up to isomorphism, so there is no single class of objects that might satisfy axioms. Rather, an axiomatic system can be applied to "infinity of system of basic objects". ${ }^{4}$ More precisely, if there is a structure defined over domain $D$ that satisfies axioms, there is always another structure defined over a domain $D$ ' whose elements can be mapped into $D$ by a one-to-one relation. That is precisely why axioms cannot fix the extension of terms that they allegedly define, as Frege later remarked. ${ }^{5}$

\subsubsection{Disguised Definitions}

Many interpreters of Poincaré's philosophy make no difference between implicit definitions and what Poincaré calls "disguised definitions" (définitions déguisées). Even though Poincaré stresses that axioms are never true or false as Hilbert did, axioms, as Poincaré understands them, do not fulfil the task assigned to Hilbertian implicit definitions. By the same token, the variant of conventionalism that Poincare proposes cannot be taken as an instance of instrumentalism (for, as I said, the conception of axioms as implicit definitions is a defining trait of instrumentalism). The reason is that Poincaré never makes a distinction between "pure" and "applied" theories. It never

\footnotetext{
${ }^{3}$ See his Gergonne (1818-9).

${ }^{4}$ See Frege \& Hilbert (1992).

${ }^{5}$ See Frege \& Hilbert (1992, p. 232). Frege conceives axioms in a different fashion. In Frege's opinion, axioms never define. For him, signs are already meaningful before becoming constituents of axioms because for each axiomatic theory there is a specific domain whose elements are designed by terms of the theory.
} 
comes into Poincaré's mind that any geometry worth of its name might be detached from the real space as it would beif it were a set of analytic a priori statements.

Not being analytic, axioms are not synthetic aposteriori either. Empiricism cannot answer the question what reasons for the choice of a geometry are. Poincaré's principal argument against empiricism in the philosophy of geometry is that geometries can never be submitted to an empirical test in isolation from a physical theory. They are always brought under empirical control along with physics, so when facing conflict with observation, scientists are free to give up either the physical theory or the geometry that the physical theory relies on. ${ }^{6}$ Here Poincaré's conclusion is quite duhemian: in case of geometries, crucial experiments are out of reach.

Might Kant's philosophy be of some help in shedding some light on the epistemic status of geometries? Poincaré's answer is a clear "no". Poincaré gives two arguments against Kant's philosophy of geometry. Both are based on relative consistency proofs. ${ }^{7}$ First, if axioms and theorems of non-Euclidean geometries were synthetic a priori judgements, it would not be possible to conceive the negations of Euclid's postulates, yet nothing stands in the way of such a possibility as relative consistency proofs have clearly showed. Second, Poincaré designs a thought-experiment. Imagine, Poincaré appeals to imagination of his readers, heightless bi-dimensional creatures that live on a spherical surface they cannot watch from above. They are confined to their spherical world. According to Poincaré, they would give preference to a Riemannian twodimensional spherical geometry, because it suits better the world they live in. ${ }^{8}$

And Poincaré goes on to conclude: traditional philosophies of geometry cannot offer a plausible answer regarding the question Poincaré addresses. All traditional philosophies are obsolete, since they cannot deal with the issue of epistemic status of geometries given the emergence of non-Euclidean geometries. However, that is not to say that Poincaré leaves everything from the past behind.

Poincaré opposes himself to Kant, yet his own philosophy is full of Kantian insights. It is true of Poincaré's philosophy of arithmetic. There is no other option but to take the principle of complete induction as a synthetic a priori judgement. ${ }^{9}$ The principle of recursive reasoning must be an ampliative judgement, since in all explicative judgements conclusions are already contained in the premises. If the

\footnotetext{
${ }^{6}$ See Poincaré (1891).

${ }^{7}$ A relative consistency proof asserts relates the consistency of a theory to the consistency of another theory. A relative consistency proof of non-Euclidean geometries says that nonEuclidean geometries are consistent if Euclidean geometry is consistent.

${ }^{8}$ See Poincaré (1891). See also Poincaré (1992).

${ }^{9}$ The principle of complete induction says that theorems that are true for number $1, n$ and $n+1$ are true for all positive integers. See Poincaré (1891, p. 773).
} 
principle of complete induction was not taken as an ampliative judgement, it would not be possible to explain how science could be a source of new information. The principle of complete induction reveals the real need of intuition in mathematics. ${ }^{10}$

The said principle has a unique status in Poincaré's philosophy. Poincaré places it on the top of his hierarchy of sciences. For all sciences presuppose arithmetic, they are all so to speak synthetic a priori laden. Geometries are not exceptions. For Poincaré, a geometry is always a study of one of Lie's transformation group. Poincaré accepts not only Lie's group-theoretical approach but also so-called Lie's theorem which reduces all geometries to three, namely Euclidean geometry, Riemannian geometry (with constant positive curvature), and Lobatschewskian geometry (with constant negative curvature). Can the choice be done on purely empirical grounds? Again, Poincaré's answer is "no". That is not to say that experience plays no role in the choice of a geometry. Even though Poincaré is unhappy with empiricism, empiricism does not go overboard in his philosophy. First and foremost, Poincaré is a genetic empiricist. According to him, every geometry is of empirical origin. Geometries originate in "successions of sensation" caused by our experiences with solid bodies. Axioms are statements of empirical regularities which were transformed into "principles". ${ }^{11}$ Even though experience cannot provide sufficient epistemic reasons for the choice of a geometry, it can still highlight the most useful one. "The choice is free, yet not arbitrary," as Poincaré says.

So what is the epistemic status of axioms? Axioms are neither analytic nor synthetic. When Poincaré says that axioms are conventions or disguised definitions, he expresses his conviction that there is no room for axioms in the traditional trichotomy of judgements. Axioms combine traits of all elements of the Kantian scheme. They are of empirical origin, yet experience cannot refute them, since they determine meanings of expressions. Contrary to analytic statements, axioms do not function as mere meaningpostulates. Often not differing from empirical statements, axioms determine objects of knowledge. Axioms are principles in the "guise of factual statements". As distinct from "ordinary" definitions, disguised definitions have negations which are not contradictory and that is why there is nothing incoherent about negations of postulates of Euclidean geometry.

\subsection{Conventionalism and Theory of Knowledge}

According to Poincaré, axioms of a geometry are neither true nor false. On a different occasion, he says that axioms are "rigorously true". Logical positivists misunderstood

\footnotetext{
${ }^{10}$ See Poincaré (1992).

${ }^{11}$ See below.
} 
Poincaré when they took Poincaré's theses on the relationship between the truth and conventions as an argument for a form of empiricism they defended.

For Positivists, conventions are neither true nor false because they are implicit definitions. Being analytic, conventions can only be true if "truth" stands for "coherence with other sentences".

There are two main reasons why conventions might lack truth values (here "truth" as applied to sentences is taken in sense of "truth by correspondence"). First, there might be no mathematical realities that mathematical statements refer to. As the necessity of mathematical statements is a matter of linguistic conventions, there is no need to assume the existence of mathematical realities. Second, theories can be taken for nothing but calculi that help to deal with the empirical content in the simplest possible way. If theories manage to do so, they are empirically adequate. There is no reason to care about whether phenomena theories capture are real or not. It is never the truth that theories aim at but their empirical adequacy. Conventionalists' understanding of the relationship between the truth and conventions gave rise to the "linguistic conventionalism" or "instrumentalism".

\subsubsection{Linguistic Conventionalism}

According to linguistic conventionalism, concepts of axiom, convention, implicit definition, analytic statement, and necessary statement can be used interchangeably. Axioms are implicit definitions that are meant to play a role of meaning-postulates. Axioms, when understood as definitions of primitive terms, are conventional, since scientists could have chosen different definitions. Implicit definitions can be understood in two different ways.

First, implicit definitions can be constructed as propositional functions. According to this account, to define a sign $F$ in a propositional function $\# F$ is to accept $\# F$ as true. $F$ gets thus a meaning needed to make $\# F$ true. But that is not the way that Schlick and other Linguistic Conventionalists understand implicit definitions. For them, to define implicitly a concept is to indicate its relations to other concepts without reference to anything outside the language. There is no need to take anything real into account; relations among concepts are enough to do the job. Axiomatic systems are formal structures devoid of any content. Such a system cannot be applied to reality unless it is related to a theory that expresses contents ("physical theory"). Hilbertian approach transposed into the epistemology has two important consequences. First, crucial experiments are out of reach. When facing a conflict with observation, scientists are free to modify either axioms or physical theory in order to re-establish the equilibrium. Second, it is convenient to choose the simplest conjunction of an axiomatic system plus a physical theory. 
An attempt to isolate the conventional part from the empirical one are often qualified as "instrumentalism". According to Instrumentalists, all signs are divided into two groups: theoretical vocabulary and empirical vocabulary. As far as theoretical vocabulary is concerned, statements formulated in this vocabulary are "apparent". They lack truth values, since they do not describe. The task of theoretical vocabulary is confined to derivation of consequences from empirical vocabulary. Theoretical vocabulary is, to put it in Ernest Nagel's words, a logical skeleton for empirical flesh. ${ }^{12}$ The hope of supporters of instrumentalism is to get by with references of empirical vocabulary without assuming theoretical entities. The point of this version of instrumentalism is ontological. It is a form of anti-realism.

Instrumentalists elaborate on the Kantian theme "thoughts without content are empty, intuitions without concepts are blind". ${ }^{13}$ Knowledge is always a result of receptivity and spontaneity. Logical Positivists take the symmetry between concepts and intuitions as a starting point of their theory of meaning. According to the instrumentalist theory, theories are systems of implicit definitions waiting to be filled with empirical contents. Forms which are related to the same contents are synonymous, hence the languages which express them are mutually translatable.

The instrumentalist theory of meaning is often considered an antidote against the incommensurability thesis. It is a convenient means of showing that there is a progress in science. What was once taken by Kuhn et al. as a scientific revolution is nothing but a form-shift without any cognitive impact whatsoever. The only thing which changes is the way of talking about contents which are invariant, hence there is no meaning variance.

From the epistemological point of view, the instrumentalist theory assigns to languages an auxiliary role. Knowledge has to be expressed in a language but languages never affect the factual relations they describe. Languages are nothing but façons de parler about these relations expressed in empirical vocabulary. Only those expressions which belong to the empirical part of vocabulary are meaningful; theoretical expressions have no meaning.

\subsubsection{Anti-instrumentalist Conventionalism}

The anti-instrumentalist version of conventionalism is based on two theses. First, there is no difference between conventional and theoretical vocabulary. Every expression is

\footnotetext{
${ }^{12}$ See Nagel (1979).

13 "Gedanken ohne Inhalt sind leer, Anschauungen ohne Begriffe sind blind.” Kant (1967, p. 95.)
} 
meaningful, since meanings are assigned to expressions by the language to which they belong. Second, from the epistemological point of view, statements cannot be taken on a par. There are "paradigmatic propositions" or "principles" (in Poincaréan sense) which are both analytic and synthetic (in the traditional Kantian sense). Contrary to Kant, anti-instrumentalists do not consider "a priori" as synonymous to "apodictic". Their concept of a priori is relativized, yet still preserving its constitutive function. Conventions take the place of Kantian categories. In what follows, I will try to shed some light on what characteristic theses of anti-instrumentalist conventionalism are; a third version of conventionalism that is neither linguistic nor trivial. Discussion will focus on two topics: the role of language in cognition and the role of conventions in justification of knowledge. According to anti-instrumentalist conventionalism ("constructivism" henceforth), facts are created. Not by innate faculties as Kant thought but by language. The choice of a language is free, yet it has important bearing on the content of knowledge; not only the form.

\section{Language, Cognition and Knowledge}

The concept of knowledge is ambiguous. It can refer to cognitive actions ("cognition" for the sake of brevity) or to results of cognitive actions ("knowledge"), so when answering the question concerning the role of language in knowledge, we should be careful whether we are dealing with the psychological or epistemological formulation. The former formulation deals mostly with the origin of knowledge; the latter is about its justification.

\subsection{Language and Cognition}

As far as cognition is concerned, the most pressing question is to know whether there are cognitive actions which are not expressed (or for some reason cannot be expressed) in a language. There are three basic answers to the question what is the relationship between cognitive actions and linguistic ones: identity ("Every cognitive actions is linguistic."), inclusion ("Some of cognitive actions are linguistic; some are not."), exclusion ("There is no such action that is cognitive and linguistic."). First and second answer might be a starting point of a view that takes languages as "distorting mirrors". Languages might be "obstructions" preventing us from knowing the reality "as it is". ${ }^{14}$ For this very reason, those who defend realism try to rule out the possibility of linguistic distortion from the very outset. According to them, cognitive actions always precede linguistic actions, so the latter cannot be deformed by the former. Speakers endow signs with meanings depending on their knowledge of objects the expressions refer to. First,

\footnotetext{
${ }^{14}$ See for instance Davidson (1997).
} 
people know; then, they confer meanings. As Polish Phenomenologist Roman Ingarden famously pointed out: "It is not true that in the beginning was the word." ${ }^{15}$ In the beginning was a cognitive action that became a linguistic one. It is a theory of language that can be labelled, paraphrasing Plato's Cratylus, "Hermogenian". According to theories of this kind, expressions are first and foremost means of reference. They are conventional labels whose primary purpose is to refer to objects that are independent of languages. Expressions get their meanings from references; from the way that objects are given to language speakers.

\subsection{Theories of Meaning: de facto vs. de jure}

All theories of meaning can be divided into two types. According to theories de facto, meanings are reducible to empirical regularities. Meanings are identified with events, habits, dispositions, etc. Hermogenian theory is a theory of such kind, since its starting points are speakers which use expressions in a regular way. For factual theories, meanings are always exterior to languages. According to theories de jure, there is no need to take in account anything except linguistic rules. Theories de jure are strictly internalist.

What is the difference between regularities and rules? The basic one is this: rules can never be falsified. Rules are used prescriptively whereas regularities are descriptions of facts about language speakers and their environment. In contrast to empirical de facto theories, theories de jure focus on the normative dimension of discourse which is out of reach for theories de facto.

\subsubsection{Normativity of Meaning}

Normativity thesis says that expressions ought to be used depending on what they mean. It is wholly dependent on meanings whether expressions are used correctly or incorrectly. Normativity thesis cannot be satisfactorily explained in a theory de facto of a Hermogenian kind, since speakers themselves decide upon meanings given to expressions, so, strictly speaking, the idea of mistake in linguistic practice does not make a sense. Theories de jure suit the job better. Mistakes can be detected through comparing linguistic practices with rules. On that account, rules are ideal patterns of linguistic usage. Rules set the criteria for correct usage of expressions that is, in its turn, a sine qua non for mutual understanding. There can be no understanding without meanings. Understanding is possible because of meanings. Rules must be obeyed by those who want to be considered language users. A person $P$ understands a language $L$ if she uses forms belonging to $L$ correctly, that is if she uses expressions of $L$ with

\footnotetext{
${ }^{15}$ See Ingarden (1972).
} 
conformity to meanings they have in $L$. To give a proof of understanding, $P$ has to respond correctly, that is in the way specified by rules. Only those persons who obey rules are considered users of the given language. They give partial reasons to be admitted into the linguistic community. Two persons, say $P_{1}$ and $P_{2}$, understand each other if both $P_{1}$ and $P_{2}$ obey rules of $L$. In such a case, $P_{1}$ and $P_{2}$ are in "logical space of reasons" of $L$.

\subsubsection{Ideality of Meaning}

If the way the expressions ought to be used depends on what they mean, each of them should have just one meaning. If the condition was not met, it would not be possible to decide, for any us age, whether expressions were used correctly or not. To put it differently, if we require a clear-cut criterion, we have to remove vagueness . According to theories de jure, there is nothing to meanings except linguistic rules, so rules should "fix" meanings. A set of rules should be "saturated" by not allowing any further extensions. The set is "saturated" if it becomes a different set when a new rule is introduced. In this case, meanings are taken to be "ideal". Meanings are ideal inasmuch as they do not change within a language.

In languages, whose rules confer ideal meanings, any change with respect to meanings - change in the language - is the change of the language, so lexical borrowings from other languages are precluded. An expression $E$, taken from one "closed" language, say $L_{1}$, and introduced to an another one, say $L_{2}$, becomes in $L_{2}$ a different expression for it changes its meaning (of course, in case $E$ does not have a synonym in $L_{2}$ and it enters to semantic relations with expressions of $L_{2}$ ). $E$ does not carry with itself its original meaning. By the same token, $L_{2}$ becomes a different language whose expressions cannot be translated into those of $L_{2}$.

In many respects, "closed" languages are peculiar. A person who breaches a single rule ceases to speak the given language. In "closed" languages, regulative rules are constitutive, since only those actions that conform to the rules count as linguistic ones. Actions conforming to rules are constitutive for linguistic actions. Rules are supposed to play that double role. On one hand, rules depend on meanings of expression, on the other, only those who obey the rules are considered language users. There is no meaning-intention independent of the rules. An action that conforms to the rules is an action that takes place because of the rules. To put it differently, from the viewpoint of theories de jure, "meaning engendered normativity thesis" is "normativity determining thesis". ${ }^{16}$ Meanings do not only have normative consequences but the very nature of meanings is normative.

\footnotetext{
${ }^{16}$ See Glüer-Pagin \& Wikforss (2009).
} 


\subsection{Language and Knowledge}

The question about the relationship between language and knowledge can be restated as follows: are products of cognitive actions always expressed in a language? If the answer is "yes", any theory of meaning is converted into a theory of knowledge.

This problem is different from that on the level of actions. To borrow once again the "glassy" metaphor from above: does the content of a linguistic image of the world (justified knowledge of the world expressed in a language) depend on the choice of language or can it be justified by means of experience? To put it differently, does experience provide sufficient reason for knowledge? If not, is knowledge "laden" with non-empirical elements?

\subsubsection{Active Role of Language in Knowledge}

The view assigning an active role to language has three basic presuppositions:

(1) Knowledge must be expressed in a language.

(2) Knowledge must be the object of propositional attitudes. Or, to put it differently: knowledge must be identical with meanings of expressions.

Neither (1) nor (2) are enough to assign an active role to language; it is only a necessary condition, for (1) is satisfied by instrumentalism. (2) is in agreement with a form of epistemological realism according to which beliefs are justified by facts independent of language. Those philosophers who assign an active role to language defend even stronger thesis. They supplement (1) and (2) with

(3) Knowledge must somehow depend on language.

For them, language is not only a condition sine qua non for justification but justification is done through languages, so the products of cognitive actions are dependent on them.

(3) can be further strengthened by

(4) There are languages which are not mutually translatable.

In virtue of (4), the choice of a language receives a substantial role from an epistemological point of view. Theses (1) - (4) amount to a view which can be labelled "radical conventionalism". It is a form of constructivist conventionalism that defends a form of incommensurability thesis. 


\subsubsection{Rational Knowledge}

Only knowledge which is expressed in a non-metaphorical way in a language can be submitted to the inter-subjective control (justification). Only such knowledge can be qualified as "rational". As Poincaré says in Poincaré (1905):

"Such, therefore, is the first condition of objectivity; what is objective must be common to many minds and consequently transmissible from one to other, and as this transmission can only come by that 'discourse' which inspires so much distrust in Mr. Le Roy, we are even forced to conclude: no discourse, no objectivity."

Reference to sensations cannot do the job, since

"[...] sensations of others will be for us a world eternally closed. We have no means of verifying that the sensation I call red is the same as that which my neighbour calls red."

According to Poincaré, language is a necessary condition of inter-subjectivity (or "objectivity", as Poincaré himself prefers). All knowledge has to be justified and this is not possible without a language. For Poincaré, the concept of "private knowledge" is a misnomer. Sensations are not reasons which might justify knowledge. Poincaré rejects firmly what Sellars will later call "the myth of the given".

\subsubsection{Verbalized Knowledge}

Theory of meaning is a theory of knowledge if only if knowledge has to be expressed in a language. Those who assign an active role to languages strengthen the idea of a semantics of knowledge. For them, languages are "schemes of justification". In their opinion, justification is not a relation between beliefs and the reality. It is a relation between one (or more beliefs) which is (are) already justified and a belief (or beliefs) which stand in need of justification. The key to understanding their thesis is their concept of rule. On one hand, rules are needed to do the justice to the normativity thesis; on the other hand, the very same rules are rules of justification. Let me explain. Only that person who obeys linguistic rules can be taken as a person knowing meanings of expressions that she employs. She possesses concepts. If knowledge is identical with meanings, such a person shows that she has a reason to convey the proposition expressed by a given sentence. She asserts a proposition which counts, for language speakers, as justified. From their viewpoint, she passes a test. For them, she knows on which occasions she is authorized to employ expressions. On the constructivist account, there is no difference between correct usage of expressions and justification of beliefs. 


\section{Conventions and Justification}

Conventionalism is not an epistemological irrationalism. None of prominent Conventionalists think that the choice of conventions is done in a wholly whimsical fashion. Neither Poincaré not instrumentalist followers from the Vienna Circle think so. In their opinion, conventionalism is a thesis that draws attention to the fact that there is an empty space between our theories and the experience waiting to be filled with conventions. Conventionalists nonetheless differ with respect to the specific view on that space and the way it should be bridged.

According to Instrumentalists, languages are forms that express empirical contents. The choice of a language cannot be decided empirically, since forms and contents are separated from each other. There are always reasons to give a preference to some conventions although they are pragmatic at best.

For Constructivists, experience cannot determine the contents of beliefs. Contents are partially dependent on languages that express them. Contrary to Instrumentalists, Constructivists admit partial epistemic justification of conventions. In their view, conventions have a "strange double nature". On one hand, conventions are of empirical origin; on the other, they determine the content of experience. Constructivists thus highlight complex relationships between conventions and experience.

\subsection{Conventions and Experience}

What is the reason to introduce the concept of convention into the philosophy of science? Conventions are often considered as an antidote against vagueness. Expressions that scientists use in their theories are often borrowed from everyday language (e.g. "simultaneity", "length" etc.). Their meaning is such that they cannot provide unambiguous criteria of application. There are always cases when expressions are used neither correctly nor incorrectly. Of course, this is at odds with the normativity thesis according to which expressions have right or wrong uses in virtue of being meaningful. The task of semantic conventions is to "sharpen" meanings of ambiguous expressions. On that account, conventions act like meaning-postulates that remove vagueness from meaning of expressions. Sentences which have determinate usage only after having accepted some conventions regarding its constituent expressions are often qualified as "interpretative". ${ }^{17}$ Interpretative statements are contrasted with so-called observational statements which can be decided without the necessity of relying on some semantic conventions. Observational statements can be decided solely on the virtue of

\footnotetext{
${ }^{17}$ See Giedymin (1982).
} 
experience. Experience alone is the sufficient criterion to determine whether expressions in observational statements were employed correctly or incorrectly.

\subsection{Conventions and Arbitrariness}

According to its detractors, conventionalism is at odds with the standard view of science. According to the standard view, science is an enterprise which aims at objectivity whereas Conventionalists promote arbitrariness. Let's first consider the case of instrumentalism. Driven by the desire to give an empiricist-compatible account of science, Instrumentalists address the issue of necessity. So-called necessary statements are nothing but consequences of conventionally accepted formation and transformation rules, so there is no reason to appeal to some cognitive capabilities beyond empirical experience (e. g. intuition). For Instrumentalists, this is a simple solution to a once worrisome problem with accommodation of necessary statements within an Empiricist framework. Necessary statements are conventions with their consequences. There is no other constraint on conventions but the internal consistency.

Even though there is no necessity to appeal to external facts that might possibly ground conventions, conventions have to be justified at least pragmatically. Given a task to accomplish, there are always some conventions that are more purposeful than others. The problem that instrumentalist account faces can be thus stated as follows: if conventions are not factually anchored, it seems that it is hard to do the justice to the normativity thesis. This is a point that Quine makes in Truth by Convention. ${ }^{18}$ Quine's famous argument goes like this: grant Instrumentalists that logical laws are conventional, as they wish they were. However, still there must be some external grounds for conventions if they are to be binding for those who follow them. Conventions needn't hung in the air, if they are supposed to serve as standards of correctness. There is no distinction between the correct and the incorrect without that external ground. For Quine, conventionalism goes by the board once we realize that the infinite regress it stumbles over can be avoided only if we appeal to something that is not conventional, hence the failure of conventionalism.

\subsection{Against Arbitrariness}

While defending themselves against the objections, Conventionalists attempt to show that although there is no factual underpinning for conventions, it does not mean that conventions are arbitrary. "Free, yes; arbitrary, not," as Poincaré put it nicely in his 1902 book. ${ }^{19}$ Scientists could have come to an agreement over different conventions,

\footnotetext{
${ }^{18}$ See Quine (1936).

${ }^{19}$ Poincaré (1992, p. 102).
} 
yet there are some reasons why they have chosen these conventions, so conventions never are arbitrary.

As Instrumentalists adhere to "top-down approach", this simple line of defence against the detractor's objection is out of reach. According to Instrumentalists, empirical research begins only after having found an empirical application for previously uninterpreted axiomatic systems ("interpretation"). The constructivist approach is "bottom-up". According to Constructivists, scientists start with hypotheses and they end up with principles. Poincaré qualifies such a procedure as "erection of laws into principles". ${ }^{20}$ According to him, scientists are free to do so only if the laws have received a sufficient confirmation from experience.

Contrary to hypotheses, Poincaréan principles are "strictly universal". Strict universality allows to decide, for any object, whether it falls under the given concept. A simple example taken from chemistry will help to elucidate what the idea of strict universality is about:

(P) Given a standard pressure, phosphorus melts at the temperature of 44 degrees Celsius.

Up to now, chemists have not had a chance to find a piece of phosphorus which does not melt at $44^{\circ} \mathrm{C}$. One can say that $(\mathrm{P})$ is an empirically well-confirmed hypothesis. Now suppose that chemists discover a mineral which has all the properties of phosphorus except its point of fusion. What might their reaction be? Basically, they could answer to such a surprising discovery in two different ways: first, they might be tempted to conclude that it is not always the case that phosphorus melts at $44^{\circ} \mathrm{C}$; second, they might eventually come to say that the strange mineral is not phosphorus. Everything depends on how $(\mathrm{P})$ is understood. In the first case, $(\mathrm{P})$ is considered a hypothesis that expresses an empirical regularity and the reaction of chemists amounts to a revision of $(\mathrm{P})$. In the second case, $(\mathrm{P})$ is taken as a rule saying how "phosphorus" ought to be used. Their reaction is a meaning-change.

(P) highlights the peculiar role of experience in knowledge. On one hand, $(\mathrm{P})$ expresses knowledge acquired through generalization; on the other hand, it determines the meaning of "phosphorus". The use of $(\mathrm{P})$ is, as it were, both descriptive and prescriptive, since it says something about a chunk of matter and simultaneously it sets standards how the expressions ought to be used. Statements like $(\mathrm{P})$ reveal that rules do not always need to have a meta-linguistic form. From the formal point of view, there is no difference between regulative and constitutive rules. It is not the form but the intention with which the statements are used which decides about their epistemic

\footnotetext{
${ }^{20}$ See especially Poincaré (1992, pp. 161-164).
} 
statuses. On one hand, empirical statements can become standards of correctness; on the other hand, norms can be "downgraded". A principle can become an empirical statement again without changing its form if language users decide to do so. In such a case, the principle is said to be abandoned. Principles are never abandoned as false for a simple reason: they do not have truth-values. Even though principles might look like empirical statements, they do not behavelike that. As Poincaré put it nicely with respect to mechanics:

"The principles of mechanics are therefore represented to us under two different aspects. On the one hand, they are truths founded on experiment, and verified approximately as far as almost isolated systems are concerned; on the other hand, they are postulates applicable to the whole of the universe and regarded as rigorously true."21

Some hypotheses are actually rules in disguise and vice versa. That is why Poincare is driven to forge a new epistemic category for his "principles". Principles are neither synthetic nor analytic; principles are conventional.

Contrary to Logical Positivists or Instrumentalists, Poincaré has a story about the origin of conventions to tell. Geometry originates with psychological laws of succession of sensations which are caused by solid bodies. Despite that fact, geometries are not empirical sciences. Empirical laws give rise to algebraic structures (groups of transformation) and this is why "geometry has nothing to fear from experience." ${ }^{22}$ Still, experience has a lot to say throughout the choice of a group of transformation. The choice is by no means arbitrary, since it depends on how "the world is". Poincaré thus bridges quite easily the gap between external objects in the extra-linguistic reality and sensations that external objects cause. For Poincaré, geometries are "deep-rooted" in the world. ${ }^{23}$ If physical regularities considerably changed, theoretical constructs that are based on them would collaps; they would lose, as Wittgenstein says, "their point". Poincaré encapsulates these two-way relations between experience and theories with a pertinence which is so typical of him:

"In fine, it is our mind that furnishes a category for nature. But this category is not a bed of Procrustes into which we violently force nature, mutilating

\footnotetext{
${ }^{21}$ Poincaré (1992, pp. 135-136).

${ }^{22}$ Poincaré (1992, p. 92).

${ }^{23}$ In his period following Philosophical Grammar, Wittgenstein makes points which are quite similar to the conclusions Poincaré came to. Rules are based on behavioral regularities. Regularities in behavior presuppos regularities in nature, which in turn presupposes solid bodies. See especially Steiner (2009). Surprisingly enough, Steiner does not compare Wittgenstein's views with Poincaré's.
} 
her as our needs require. We offer to nature a choice of beds among which we choose the couch best suited to her stature." 24

According to Poincaré (and late Wittgenstein), we begin with empirical regularities (hypotheses, laws) which are approximately true and we end up with principles (conventions, rules, axioms, disguised definitions) which are empirically irrefutable, since they are necessary conditions for empirical experience. That does not mean that principles are arbitrary. Again, let Poincaré speak:

"Are the laws of acceleration and of the composition of forces only arbitrary conventions? Conventions, yes; arbitrary, no. They would be so if we lost sight of the experiments which led the founders of the science to adopt them, and which, imperfect as they were, were sufficient to justify their adoption. It is well from time to time to let our attention dwell on the experimental origin of these conventions." 25

To sum up, Poincaré draws conclusions that are quite opposed to theses of logical positivism or instrumentalism. According to Poincaré, languages are structures built upon bedrock of facts. It is a form of conventionalism, since facts do not determine theoretical structures that are built upon them. Theories are under-determined, yet, to repeat, they are not wholly independent on facts. Facts restrict the number of superstructures leaving only those which are admissible. Poincaré's conventionalism is still a "philosophy of freedom", but freedom does not imply arbitrariness. There is a partial epistemic justification for Poincaré's principles.

There are some other differences between Poincaré's conventionalism and instrumentalism. First, it is possible to perform an experiment which might be considered crucial. Even though experience alone cannot arbitrate the choice of a theory among competing ones, in the interior of the theory - once a theory is decided upon - crucial experiments are possible because of strict universality of theoretical principles, since, for any object, it is always possible to decide whether it is part of the extension. Second, the "strange double nature" of principles reveals that empirical and conventional elements can be merged in a single statement without the possibility to separate them each other. To put it differently, Poincaré blurs the distinction between analytic and synthetic. This has further consequences for the relation between experience and theories. Again, the Kantian dictum "thoughts without content are empty, intuitions without concepts are blind" will help to get a better grip on the idea. Although being a necessary condition for empirical knowledge, sensations are not enough for empirical knowledge. The empirical input must be conceptualized. As Polish

\footnotetext{
${ }^{24}$ Cited after Ben-Menahem (2006).

${ }^{25}$ Poincaré (1992, p. 133).
} 
microbiologist, Ludwik Fleck, put it nicely: someone who looks does not see, if she does not know first. ${ }^{26}$ She must know concepts, that is meanings of expressions employed for conceptualization of the experimental input. So far the second part of the Kantian dictum was explained. What about the first part of the dictum? Are thoughts without content empty? According to Poincaré and contrary to Instrumentalists, concepts are not "empty", so there is no need to interpret them. Let's take again a statement like (P). At first glance, it looks like a mere verbal stipulation or definition but actually it is not. It is a, to borrow Wittgenstein's metaphor, a "petrified regularity". According to Poincaré (and Wittgenstein), principles (or rules) are perceptual. Experience is not only theory-laden but theories are empirically saturated. This is another reason, probably the most important one, why we should come to the conclusion that Poincaré's conventionalism is not an instrumentalism.

\section{Bibliography}

Ben-Menahem, Y. (2006): Conventionalism. Cambridge University Press, Cambridge.

Davidson, D. (1997): “Seeing Through Language.” In Thought and Language, ed. J. Preston, Cambridge University Press, Cambridge, 1997, pp. 15-29.

Duhem, P. (1906): Théorie physique. Son objet et sa structure, Chevalier \& Rivière, Paris.

Fleck, L. (1947): “To Look, To See, To Know." In Cognition and Fact. Materials On Ludwik Fleck, eds. R. S. Cohen \& T. Schnelle. Kluwer, Dordrecht, 1986, pp. 129151.

Frege, G. \& Hilbert, D. (1992): “Correspondance.” In Logique et fondements mathématiques. Anthologie, (1850-1914), eds. F. Rivenc \& P. de Rouilhan, Payot, Paris, 1992, pp. 215-235.

Gergonne, J. D. (1818-9): "Variétés. Essaie sur la théorie de la définition." Annales de Mathématiques pures et appliquées 9: 1-35.

Giedymin, J. (1982): Science and Convention: Essays on Henri Poincaré's Philosophy of Science and the Conventionalist Tradition. Pergamon Press, New York.

Glüer-Pagin, K. \& Wikforss, Å. (2009): “The Normativity of Meaning and Content.” In Stanford Encyclopedia of Philosophy. [online] available from:

<http://plato.stanford.edu/archives/win2010/entries/meaning-normativity/>

Hempel, C. G. (1945): “On the Nature of Mathematical Truth.” American Mathematical Monthly 52: 543-556.

\footnotetext{
${ }^{26}$ See Fleck (1947).
} 
Ingarden, R. (1972): “O języku i jego roli w nauce.” In Z teorii języka i filozoficznych podstaw logiki, R. Ingarden, PWN, Warszawa, 1972, pp. 29-119.

Kant, I. (1967): Kritik der reinen Vernunft. Meiner Verlag, Hamburg.

Le Roy, E. (1899): “Science et philosophie.” Révue de métaphysique et de morale 7: $375-425$.

Le Roy, E. (1900): "Science et philosophie. Suite et fin." Révue de métaphysique et de morale 8: 25-75.

Le Roy, E. (1901): “Un Positivisme nouveau." Revue de métaphysique et de morale 9: 138-53.

Nagel, E. (1979): The Structure of Science: Problems in the Logic of Scientific Explanation. Hackett Publishing, Indianapolis \& Cambridge.

Poincaré, H. (1891): “Géometries non euclidiennes.” Révue générale des sciences pures et appliquées 23: 769-74.

Poincaré, H. (1992): Science et hypothèse. La Bohème, Rueil-Malmaison.

Poincaré, H. (1905): La valeur de la science. Flammarion, Paris.

Quine, W. V. O. (1936): “Truth by Convention.” In The Ways of Paradox and Other Essays, Harvard University Press, Cambridge, MA, 1997, pp. 77-106.

Steiner, M. (2009): "Empirical Regularities in Wittgenstein's Philosophy of Mathematics." Philosophy of Mathematics 17: 1-34.

Twardowski, K. (1912): “Action and Products. Comment on the Border Area of Psychology, Grammar and Logic." In On Actions, Products and Other Topics in Philosophy, eds. J. Brandl \& J. Woleński, Rodopi, Amsterdam \& Atlanta, 1999, pp. 103-132. 